\title{
AUTHOR'S SELF-REPRESENTATION IN RESEARCH ARTICLES BY ANGLOPHONE AND SLOVAK LINGUISTS ${ }^{1}$
}

\author{
Milada Walková
}

\begin{abstract}
The tension between the need to present oneself in academic discourse unobtrusively on the one hand and promotionally on the other hand results in a range of options of hiding and revealing authorial presence in the text. The choice from among these options is, among other factors, determined by cultural background. This paper explores how Anglophone writers and Slovak authors writing in Slovak and in non-native English position themselves in linguistic research papers as individuals or as part of a society, and as participants or non-participants of the given communicative exchange. The study concludes that English academic culture is largely individualistic while Slovak academic culture is largely collectivist, a trait that Slovak authors also transmit into their writing in English for a mainly local audience.
\end{abstract}

\section{Keywords}

self-mention, self-reference, academic writing, academic discourse, intercultural rhetoric

\section{Introduction}

Communication of research findings in academia is as important as arriving to the findings themselves. Publication is vital for research to receive recognition by academic community, inform education, and foster academic debate. Successful publishing is also an important part of individual career growth, often leading to attracting grant funding, securing promotion and earning reputation. The tension between claiming membership of an academic community on the one hand and stressing one's contribution to the field on the other hand results in a dilemma how to present oneself as the author of a text: Authors of research articles can deliberately choose to minimize or to accentuate their presence in the text (e.g. Hyland 2001, 2002b). The former option enables the author to claim academic modesty and impart objectivity to the text, the latter one gives credit and credibility to the author. In fact, the use of personal pronouns in academic writing was stigmatized a few decades ago for the belief that writing in science should be void of subjective and personal elements (cf. Webb 1992, Chang $\&$ Swales 1999). Since then, a large amount of research into academic writing has shown that the use of personal pronouns enables authors to differentiate their unique research procedures and findings from the work of other scholars, to 
assume personal responsibility for their research, to persuade the reader, and to gain acceptance by the academic community (e.g. Tarone et al. 1981, Martínez 2001, Hyland 2001, 2002a). Authors from cultures which do not encourage selfpromotion may find it difficult to refer to themselves directly and may instead opt for avoidance of self-mention (Flowerdew 2001). Thus the way writers represent themselves in texts reveals their affiliation with a certain social group (Ivanič \& Camps 2001). In other words, authors' self-representation in academic discourse can inform research about underlying cultural values of the authors.

The present study aims to explore author's self-representation in texts written by Slovaks and to uncover its linguistic and cultural determinants. Working in the framework of contrastive linguistics and intercultural rhetoric (cf. Connor et al. 2008), author's self-representation in Slovak writing is compared and contrasted with (i) native English writing representing Anglophone writing conventions, and (ii) non-native English texts by Slovak authors. Self-representation is understood here as ways authors opt to present their persona in a text. It includes various personal means of self-mention, ranging from the first person that involves the readership and/or other people to exclusive first person and exclusive third person. Since previous research has shown disciplinary differences in selfmention in academic writing (e.g. Hyland 2001), this paper is restricted to the study of research papers in a single discipline, namely linguistics.

\section{Personal pronouns and self-mention in academic writing}

The use of personal pronouns, as a primary form of self-mention in academic writing, has been mapped from various perspectives, including a focus on rhetorical functions (e.g. Tang \& John 1999, Hyland 2002a, Mur Dueñas 2007), disciplinary differences (e.g. Hyland 2001, Harwood 2005, Zapletalová 2009, Lafuente Millán 2010), juxtaposition to impersonal constructions (e.g. Charles 1999, Martínez 2001, Stašková 2005, Walková 2008, Molino 2010), different sections of abstracts and articles (e.g. Martínez 2005, Pho 2008), and even peripheral genres such as bio and thesis acknowledgements (e.g. Hyland 2011, Hyland \& Tse 2012).

First person pronouns serve a variety of rhetorical functions in the text. An influential taxonomy of such rhetorical functions is given by Tang and John (1999), who propose the following continuum of authorial presence:

1. 'I' as the representative, where the pronoun, typically plural, represents academic community or people in general, e.g. the English we know today,

2. 'I' as the guide through the text, which uses reader-inclusive plural pronouns, e.g. from example 1, we observed that, 
3. 'I' as the architect of the text, which the writer uses to organize and outline the paper, e.g. In this essay, I will discuss,

4. 'I' as the recounter of the research process, which describes the writer's research procedures, e.g. the data I collected,

5. 'I' as the opinion-holder, which expresses the author's stance on established facts, e.g. I agree with Fairclough,

6. 'I' as the originator, in which the author puts forward original claims, e.g. $M y$ idea rested on the assumption.

As we can see, the reference of personal pronouns in academic writing may be exclusive to the writer (Tang \& John's functions 3-6), ${ }^{2}$ or it may involve the reader as a participant of the given communicative exchange (function 2), or it may include non-participants of the exchange as well (function 1). Whereas the first option enables the author to present him/herself as an individual, in the latter two options the author positions him/herself as part of a community or society. According to Harwood (2005), authors take advantage of this ambiguity of first person plural pronouns to engage and persuade the reader.

Yet self-mention is not limited to first person pronouns; it can be realized by a number of other forms, including self-mention terms such as the author(s) (e.g. Kuo 1999, Pho 2008), passive voice (e.g. Tarone et al. 1981), inanimate subjects (e.g. Master 1991) and anticipatory it (e.g. Hewings \& Hewings 2002). Since these options are mutually compatible, an author will draw on a range of various personal and impersonal constructions in order to both display and downplay his/ her presence at various points in one and the same text (Charles 1999, Martínez 2001). The choice of constructions is largely determined by desired rhetorical effects, but it is also influenced by the author's knowledge of the genre, culture, level of perceived authority and assumed responsibility, as well as the context of publication.

The familiarity with the genre is an issue with student writers, whose overuse of personal pronouns in academic writing has been found to decrease after a focused instruction in English academic writing style (McCrostie 2008). Once they understand the requirements of the genre, however, students and young scholars may underuse self-mention pronouns if they feel they lack the necessary authority to voice their claims (e.g. Chang \& Swales 1999, Tang \& John 1999, Hyland 2002a). Even authors with sufficient research and writing experience may avoid self-mention if they feel such an act is socially inappropriate to their cultural values and beliefs (Flowerdew 2001). Their readers, however, may have different expectations about the level of self-mention in academic writing. A clash between the writer's use of self-mention and the readers' expectations may lead to 
communication failure and rejection of the author's exposition by the academic community (Duszak 1994, 1997, Scollon 1994). Therefore, understanding the expectations of one's readership is an important issue in academic writing.

With the rise of English as a lingua franca of scientific communication, the number of academics writing in non-native English has increased. This, however, does not mean that contributors to international journals are not expected to adjust to the norms of the journal; actually, many editors find a lack of author's voice in non-native research articles to be problematic (Flowerdew 2001). The assumptions of editors and reviewers about an appropriate level of author's self-representation can influence their decision to accept or reject a paper for publication in a journal (e.g. Webb 1992). As a result of this gatekeeping effect, large international journals may foster different practices than the ones accepted in more locally-based journals: In fact, the context of publication is another factor determining author's overt presence in a research article (e.g. Burgess 2002, Mur Dueñas \& Šinkūnienė 2016 and references therein). For instance, DontchevaNavratilova (2013) has shown that self-mention in non-native English texts by Czech authors is also influenced by the target audience of the publications.

The increase in the number of publications in non-native English has turned the attention of research to academic writing in other languages and cultures, especially in comparison with English (cf. Mur Dueñas \& Šinkūnienė 2016). Anglophone academic writing style has been shown to differ from the styles of other cultures, including Slavic ones, in numerous ways (Kaplan 1966, Galtung 1981). More specifically, studies in intercultural rhetoric (e.g. Duszak 1994, Čmejrková \& Daneš 1997, Vassileva 1998, Dontcheva-Navratilova 2013, 2014, Khoutyz 2013, 2015) have shown that personal pronouns and reader engagement elements are less frequent in Slavic texts than in English ones. As a result, English writing is marked by higher authorial authoritativeness and interaction with the reader (Dontcheva-Navratilova 2013). In contrast to English academic writing, which uses a mixture of first person singular and plural pronouns, Slavic languages rarely use singular and instead use plural even in the case of single authorship as a sign of authorial modesty, unobtrusiveness and distance (e.g. Chamonikolasová 2005, Čmejrková 2007, Dontcheva-Navratilova 2013, Vassileva 1998, Walková 2014). Czech authors tend to use this so-called authorial we also when writing for Czech academic community in English, as found by Dontcheva-Navratilova (2014). According to Čmejrková (2007), authorial we is frequently joined with a high degree of epistemic modality, which is used to consider a number of options in argumentation. Čmejrková further notes that the use of the first person singular is on the rise in modern Czech and Slovak academic writing due to the influence of English. According to her findings, 
Slovak and Czech authors use the singular to put forth arguments and to present their biographical or research self. When wishing to avoid the singular, authors opt for the third person for self-mention.

We can see that Slovak has received little attention in research - to the best of my knowledge, only Čmejrková (2007) and Walková (2014) discuss selfmention in Slovak academic writing. However, both studies are purely qualitative and focus on writing in Slovak only, not discussing non-native English texts written by Slovaks. Therefore, this paper presents quantitative data of academic writing in Slovak juxtaposed to both Anglophone writing and non-native English academic writing by Slovak authors. Comparing and contrasting the three types of writing (Slovak, Anglophone, and non-native English by Slovak authors) allows us to see to what extent Slovak authors conform to the conventions of Slovak and of Anglophone academic discourse when writing in English. In addition, the paper enriches previous intercultural rhetoric research into Slavic languages by contrasting various types of inclusive and exclusive first person and of third person as manifestations of author's self-representation.

\section{Data collection and research procedure}

Three corpora of linguistic research papers were compiled: a corpus of Anglophone (native English) writing (AN), a corpus of Slovak writing (SK), and a corpus of non-native English texts written by Slovak authors (NNE). In order to represent recent trends, the corpora were built from papers published between 2012 and 2016 inclusive.

The texts in the Anglophone corpus were drawn from journals English for Specific Purposes, English Language and Linguistics, and TESL Canada. These journals were chosen for their availability through library service or open access publishing and for a large number of papers written by native English writers. For a paper to be included in the corpus, at least one of its authors had to be judged as a native speaker, as determined by his/her name and affiliation. ${ }^{3}$ The corpus of Slovak writing was built from Slovak journals Slovenská reč, Jazykovedný časopis and Jazyk a kultúra. The texts for the non-native English corpus could in principle be drawn from either international journals of large publishing houses with a wide audience or from more locally-based journals. Since the target audience and context of publication influences author's self-representation (as discussed in Section 2), there is greater probability that editors and reviewers of the former type of journals enforce Anglophone conventions (cf. Flowerdew 2001) while the latter type of journals enforce local conventions of selfrepresentation. For this reason, and in order to study local Slovak conventions of self- representation, I decided to include in the corpus articles from journals 
published in Slovakia. However, there were too few suitable papers written in English by Slovak authors published in Slovak journals. ${ }^{4}$ Therefore, papers from a periodically published edited volume were also included. Namely, the texts were taken from the volume English Matters and the journals Jazyk a kultúra, ${ }^{5}$ SKASE Journal of Theoretical Linguistics, Topics in Linguistics, and XLinguae.

In order to avoid skewing the data by writers' personal styles, care was taken to ensure that only one paper from each author was included in the corpora. Given the limited sources of articles, the data were not controlled for single vs. multiple authorship; however, this fact is taken into consideration in interpreting the results (see Section 4).

The texts were converted to a plain text file format using AntFileConverter (Anthony 2015). Some parts of the texts were then removed, such as authors' names and affiliations, abstracts, lists of keywords and references, appendices, etc. The acknowledgements sections, however, were retained, as they are an important outlet for self-mention. The length of the corpora was determined by AntConc (Anthony 2014), see Table 1. As the corpora differ in length, the results were normalized to 10,000 words (see Section 4). Since Slovak is a pro-drop language that marks the person on the verb, the texts in Slovak were additionally tagged by TreeTagger (Schmid 2009, Ó Duibhín 2016) to enable corpus search for the verb marking of the person.

\begin{tabular}{|l|r|r|r|}
\hline Corpus & Anglophone & Slovak & Non-native English \\
\hline Single-authored texts & $\begin{array}{r}100,347 \text { words } \\
(12 \text { papers })\end{array}$ & $\begin{array}{r}140,723 \text { words } \\
(27 \text { papers })\end{array}$ & $\begin{array}{r}114,344 \text { words } \\
(27 \text { papers })\end{array}$ \\
\hline $\begin{array}{l}\text { Multiple-authored } \\
\text { texts }\end{array}$ & $\begin{array}{r}152,503 \text { words } \\
(18 \text { papers })\end{array}$ & $\begin{array}{r}16,891 \text { words } \\
(3 \text { papers) }\end{array}$ & $\begin{array}{r}16,703 \text { words } \\
\text { (3 papers) }\end{array}$ \\
\hline Total & $\mathbf{2 5 2 , 8 5 0 \text { words }}$ & $\begin{array}{r}\mathbf{1 5 7 , 6 1 4} \text { words } \\
\mathbf{( 3 0} \text { papers) }\end{array}$ & $\begin{array}{r}\mathbf{1 3 1 , 0 4 7} \text { words } \\
\text { (30 } \text { papers) }\end{array}$ \\
\hline
\end{tabular}

Table 1: Description of the corpora

Using AntConc (Anthony 2014), the corpora were then searched for first person singular and plural pronouns (in all grammatical cases), verbs marked for the first person in the Slovak corpus, and self-mention terms such as autor/ ka/i 'author(s)' (in all grammatical cases), the (present/first/second, etc.) author/ researcher and the research team referring to the writer(s). The results were manually sorted in order to remove cited examples and quotations, and instances which did not refer to the authors. 
In addition, the original files were searched for authors' initials and surnames, the latter including self-citations unacknowledged as one's own previous work. Depending on their integration in the text, citations can be divided into nonintegral, which are not part of the text, such as the study of academic writing (Hyland 2001), and integral, which are part of the main text, e.g. Hyland (2001) states (Swales 1990). With this distinction in mind, I included in the data only instances where a self-citation was an integral part of the text, since the purpose was not to determine the overall number of self-citations but rather to determine the number of self-citations in which the authors present their previous work in the third person, as in Example (1), rather than impersonally (such instances are irrelevant for the present study), as in Example (2), or in the first person (note that first-person self-references would be included in the above types of search), as in Example (3).

(1) Similar findings are reported in Collins's (2009) study... (AN8)

(2) V Vnihe o sile jazyka (Dolnik, 2012) sa podáva výklad subjektivizácie... (SK5)

[In a book on the power of language (Dolník, 2012) an exposition of subjectivisation is given...]

(3) In a previous, descriptive study (Bruce, 2010), I analysed the first 10 essays of the present samples using the same genre... (AN4)

Instances where self-citations clearly referred to a work of the writers rather than their person, such as (4), were not included in the data, while ambiguous cases which can refer either to person(s) or a work, such as (5), were retained.

(4) Biber and Kurjian (2007) is exceptional in this regard. (AN2)

(5) ...Nathan (2013) defined the communicative purposes of pedagogical business case report texts... (AN20)

The data were then classified into the following categories:

1. the collective perspective:

(a) general use of the first person to refer to a nation or to people in general, e.g. the values we (= Slovaks) have (NNE15),

(b) general use of the first person to refer to an academic community, e.g. the map analysis can help us (= scholars) understand the geographic components of the imagined sociolinguistic landscape of Ohio (AN6),

(c) reader-inclusive first person plural, e.g. ako uvidíme 'as we will see' (SK7), 
2. the reader-exclusive perspective:

(a) reader-exclusive first person plural for multiple authorship, e.g. we focus here only on the two principal qualitative and quantitative methods used (AN22, three authors),

(b) reader-exclusive first person plural for single authorship, e.g. na pomenovanie výsledku univerbizácie v tejto štúdii používame termín univerbát [to name the result of univerbation, we use the term univerb in this study] (SK22, single author),

(c) reader-exclusive first person singular for single authorship, e.g. my intention in presenting these hypotheses (AN25, single author),

(d) reader-exclusive first person singular for multiple authorship, e.g. to start with, let me introduce the study programmes (NNE1, two authors), ${ }^{6}$

3. the third person perspective:

(a) author's initials, e.g. (zdôraznila D. S.) [(emphasis by D. S.)] (SK28),

(b) third person self-citations, e.g. the frequencies ... were drawn from Gumanová 's research, 2015 (NNE10),

(c) third person self-mention terms, e.g. the researchers for the current study used Ellis's definition of a task (AN10).

However, it has to be noted that the categorization of the first person plural was not always clear-cut, as "the meaning of the first person plural pronoun is often vague", i.e. ambiguous between inclusive and exclusive meanings, as pointed out by Biber et al. (1999: 329). Therefore, the linguistic context was carefully considered in each case.

\section{Results and discussion}

This section presents and discusses the results, both in terms of overall frequency and the frequency of individual perspectives followed in the study.

\subsection{Overall frequency of author's self-representation}

The results for all the three perspectives overall are shown in Table 2. As can be seen, their incidence is lower in non-native English (32.89 per 10,000 words) than in Anglophone writing (48.01 per 10,000 words), whereas Slovak makes even heavier use of author's presence ( 85.46 per 10,000 words). Sudková (2010: 54-55) arrives at the same finding for Czech, tentatively explaining it by less frequent use of the passive voice in Czech or, alternatively, attempts by Czech authors to engage the audience. Her suggestions cannot be maintained: Regarding the former one, the infrequency of the passive voice is a co-occurring phenomenon rather than a causing factor; regarding the latter, previous research (see Section 3) shows that Slavic languages feature less reader engagement than 
English. I suggest instead that the frequency of personal self-mention in Slavic texts is due to the fact that the person is (also) marked by verb endings, which appears less conspicuous than the use of preverbal, fronted personal pronouns. In fact, no occurrences of subject personal pronouns appear in my Slovak data. Similarly, Sudková (2010: 54) reports a single case of the first person subject pronoun, compared to 66 possessive pronouns and 423 first person verb endings.

\begin{tabular}{|l|rr|r|rr|r|rr|r|r|}
\hline Corpus & \multicolumn{3}{|c|}{ Anglophone } & \multicolumn{3}{c|}{ Slovak } & \multicolumn{3}{c|}{ Non-native English } \\
\hline Perspective & Raw & $(\%)$ & NF & Raw & $\mathbf{( \% )}$ & NF & Raw & $(\%)$ & NF \\
\hline Collective plural & 234 & $(19 \%)$ & 9.3 & 526 & $(39 \%)$ & 33.4 & 249 & $(58 \%)$ & 19.0 \\
\hline Reader-exclusive & 896 & $(74 \%)$ & 35.4 & 772 & $(57 \%)$ & 49.0 & 172 & $(40 \%)$ & 13.1 \\
\hline Third person & 84 & $(7 \%)$ & 3.3 & 49 & $(4 \%)$ & 3.1 & 10 & $(2 \%)$ & 0.8 \\
\hline Total & $\mathbf{1 , 2 1 4}$ & $(100 \%)$ & $\mathbf{4 8 . 0}$ & $\mathbf{1 , 3 4 7}$ & $(100 \%)$ & $\mathbf{8 5 . 5}$ & $\mathbf{4 3 1}$ & $(100 \%)$ & $\mathbf{3 2 . 9}$ \\
\hline
\end{tabular}

Table 2: The frequency of author's presence in the corpora, both raw and normalized (NF) to 10,000 words

Looking at the individual perspectives, the reader-exclusive perspective is by far the most frequent (74\%) in the Anglophone corpus. This perspective is the most frequent $(57 \%)$ in the Slovak corpus as well, although to a lesser extent, since the collective plural perspective also occurs rather often (39\%). The collective plural perspective is predominant in the non-native English corpus $(58 \%)$. Let us now turn to more detailed results for each perspective in turn.

\subsection{The collective plural perspective}

The results for the collective plural perspective can be found in Table 3. Anglophone writing is dominated by the reader-inclusive perspective $(68 \%)$, which enables the author to engage the reader in the dialogue. According to Harwood (2005: 346), "this (simulated) involvement will hopefully make the reader more receptive to the writer's claims for rhetorical effect". The writer uses the reader-inclusive perspective to guide the reader through the text (cf. Tang \& John 1999) and thus effectively decreases the distance between the two of them, as in:

(6) On a more general closing note, we can now return to Baxandall's important 1979 article... (AN26) 


\begin{tabular}{|l|rr|r|rr|r|rr|r|}
\hline Corpus & \multicolumn{3}{|c|}{ Anglophone } & \multicolumn{3}{c|}{ Slovak } & \multicolumn{3}{c|}{ Non-native English } \\
\hline Perspective & Raw & $(\%)$ & NF & Raw & $\mathbf{( \% )}$ & NF & Raw & (\%) & NF \\
\hline General: people & 22 & $(9 \%)$ & 0.9 & 244 & $(46 \%)$ & 15.5 & 150 & $(60 \%)$ & 11.5 \\
\hline General: academic & 52 & $(22 \%)$ & 2.1 & 97 & $(18 \%)$ & 6.2 & 34 & $(14 \%)$ & 2.6 \\
\hline Reader-inclusive & 160 & $(68 \%)$ & 6.3 & 185 & $(35 \%)$ & 11.7 & 65 & $(26 \%)$ & 5.0 \\
\hline Total & $\mathbf{2 3 4}$ & $(100 \%)$ & $\mathbf{9 . 3}$ & $\mathbf{5 2 6}$ & $(100 \%)$ & $\mathbf{3 3 . 4}$ & $\mathbf{2 4 9}$ & $(100 \%)$ & $\mathbf{1 9 . 0}$ \\
\hline
\end{tabular}

Table 3: The frequency of the collective plural perspective in the corpora, both raw and normalized (NF) to 10,000 words

In both the Slovak corpus and the non-native English corpus a preference is found for reference to people in general ( $46 \%$ and $60 \%$, respectively) - the reference which is only marginal in Anglophone writing (9\%). This contrast points to a collectivist nature of Slovak culture. Interestingly, though, this perspective is not formally limited to the use of plural form; to the contrary, the singular form can equally be used as a pars pro toto means of the collective perspective:

Na ilustráciu si predstavme, že v mojom vnútornom svete sa objavil dojem, ktorý jazykovo vyjadrím výpoved'ou: Mám dojem, že sused sa na mňa hnevá. Otázka z pozície ega znie, o čom vypovedá tento dojem, teda ako mu rozumiem. To, že mu rozumiem, vyplýva z jeho integrovanosti do komplexu (celku) významov spätých s mojimi zážitkami, emóciami, skúsenost’ami, racionálnymi aktivitami, motiváciami (potrebami, záujmami, želaniami, ideálmi a pod.) aj hodnoteniami a hodnotami... (SK5)

[To illustrate, let us imagine that an impression has appeared in my inner world, which I will linguistically express with the utterance I have an impression that the neighbour is angry with me. The question from the point of view of ego is what this impression signifies, that is, how I understand it. The fact that I understand it follows from its integration into the complex (whole) of meanings related to my experiences, emotions, encounters, rational activities, motivations (needs, interests, wishes, ideals, and so on) as well as evaluations and values...]

By employing this perspective, authors make the readers feel that the phenomena under discussion are relevant to everyday experience. This is a matter of presentation rather than of a choice of a subject matter, however, as can be seen from the following examples of both a reference to people in general (Example 8) and a reference to an academic community (Example 9): 
(8) Xenosy môžeme teda hodnotit' pozitívne, aj ked' je pre nás zložité ich napodobnit', ale pokladáme ich napríklad za inšpirativne. (SK7)

[We can thus judge xenoses as positive, even if it is difficult for us to imitate them but we find them inspiring, for instance.]

(9) Jedným zo základných kritérií vytvárajúcich rozdielnost’v komunikačných účeloch je typ vedeckého výstupu, pri ktorom v zásade rozlišujeme konferenčný abstrakt a abstrakt odborného článku (Stašková 2005; Swales 1990; Swales \& Feak 2000). (SK16)

[One of the basic criteria differentiating communicative purposes is the type of a research output, where in general we distinguish a conference abstract and an abstract of a research paper (Stašková 2005; Swales 1990; Swales \& Feak 2000).]

Notice that in English academic writing, impersonal constructions (such as can be judged, they are difficult to imitate, are found and are distinguished, respectively) rather than personal ones are normally used in the same context, as evidenced by low occurrence of the collective perspective in the Anglophone corpus. Slovak authors of the texts in my non-native English corpus, however, do not seem to be aware of this fact, as they employ the collective perspective to an even greater extent than is found in Slovak texts (60\% and 46\%, respectively), as in Example (10) - note that the possessive plural in the example could be, for instance, lexically substituted with human.

In science, philosophy and literature, as well as in all kinds of art, the more widely understood mimesis is inevitable, an imitation not only on the level of form, but also meaning, and not only in the phenomena from the physical world, but also in the realm of ideas that only exist in our minds. (NNE28)

\subsection{The reader-exclusive perspective}

The frequency of the reader-exclusive first person perspective is shown in Table 4. Note that the perspectives were normalized to the number of words in multiple-authored and single-authored articles separately rather than to the number of words in the whole corpus. The occurrence of the singular perspective in multiple-authored papers is shown as well, since it surprisingly appears in the data, although to a minimum extent. Note how it is used in Example (11), alongside the third person perspective (the first author) and the reader-exclusive plural (we), to retain both the personal and the individualistic nature of the given acknowledgement. 
(11) This study was conducted during the first author's work toward a MEd; I am grateful to the students and their teachers for their participation. We would both like to express our gratitude to... (AN14)

\begin{tabular}{|l|rr|r|rr|r|rr|r|r|}
\hline Corpus & \multicolumn{3}{|l}{ Anglophone } & \multicolumn{3}{|l|}{ Slovak } & \multicolumn{3}{|c|}{ Non-native English } \\
\hline Perspective & \multicolumn{2}{|c|}{ Raw } & $(\%)$ & NF & Raw & $(\%)$ & NF & Raw & $(\%)$ & NF \\
\hline SG in multiple & 1 & $(0 \%)$ & 0.1 & 0 & $(0 \%)$ & 0 & 1 & $(4 \%)$ & 0.6 \\
\hline PL in multiple & 739 & $(100 \%)$ & 48.5 & 80 & $(100 \%)$ & 47.4 & 25 & $(96 \%)$ & 15.0 \\
\hline Multiple total & $\mathbf{7 4 0}$ & & $\mathbf{4 8 . 5}$ & $\mathbf{8 0}$ & & $\mathbf{4 7 . 4}$ & $\mathbf{2 6}$ & & $\mathbf{1 5 . 6}$ \\
\hline SG in single & 145 & $(93 \%)$ & 14.5 & 67 & $(10 \%)$ & 4.8 & 44 & $(30 \%)$ & 3.9 \\
\hline PL in single & 11 & $(7 \%)$ & 1.1 & 625 & $(90 \%)$ & 44.4 & 102 & $(70 \%)$ & 8.9 \\
\hline Single total & $\mathbf{1 5 6}$ & & $\mathbf{1 5 . 6}$ & $\mathbf{6 9 2}$ & & $\mathbf{4 9 . 2}$ & $\mathbf{1 4 6}$ & & $\mathbf{1 2 . 8}$ \\
\hline Total & $\mathbf{8 9 6}$ & $(100 \%)$ & $\mathbf{3 5 . 4}$ & $\mathbf{7 7 2}$ & $(100 \%)$ & $\mathbf{4 9 . 0}$ & $\mathbf{1 7 2}$ & $(100 \%)$ & $\mathbf{1 3 . 1}$ \\
\hline
\end{tabular}

Table 4: The frequency of the reader-exclusive singular (SG) and plural (PL) first person in the multiple-authored and single-authored papers in the corpora, both raw and normalized (NF) to 10,000 words

Single Anglophone authors typically use singular perspective (93\%) - the plural perspective is rare (7\%) and appears only in four papers out of twelve singleauthored papers. This indicates the need of Anglophone authors to mark out their individual contribution, especially in the competitiveness of large international journals. In contrast, Slovak single authors typically use authorial plural when writing both in non-native English (70\%) and even more so in Slovak (90\%), as observed previously in other Slavic languages (e.g. Chamonikolasová 2005, Čmejrková 2007, Dontcheva-Navratilova 2013, Mur Dueñas \& Šinkūnienė 2016, Vassileva 1998, see Section 2). In the non-native English corpus, the singular perspective $(30 \%)$ is used in nine papers out of 27 single-authored papers. Some use of the singular perspective $(10 \%)$ can also be observed in the texts in Slovak. A closer look reveals that it is used systematically only in four papers out of 27 single-authored papers, while in three more papers its use is limited to acknowledgements. This finding confirms Čmejrková's (2007) conclusions that Slovak authors use the first person to present their biographical or research self.

Comparing the overall frequency of the reader-exclusive perspective, we find that it is higher in the papers by multiple authors ( 48.52 per 10,000 words) than in the papers by single authors ( 15.55 per 10,000 words) in the Anglophone corpus. Admittedly, this result may have been caused by the wrong categorization of 
some pronouns due to their ambiguity between inclusive and exclusive meanings, as pointed out in Section 3. Alternatively, it is possible that this very ambiguity of first person plural pronouns empowers authors to use the pronouns to a greater extent, as they appear less obtrusive than unambiguous singular pronouns. In fact, we do not find this asymmetry in the other two corpora which largely rely on the use of authorial we in single-authored texts: The incidence of the readerexclusive perspective is similar in multi-authored and single-authored papers in both non-native English (15.57 and 12.77 per 10,000 words, respectively) and Slovak (47.36 and 49.18 per 10,000 words, respectively). It follows that the use of authorial plural enables single authors to exploit the ambiguity of the plural perspective.

\subsection{The third person perspective}

The third person perspective is the least frequent form of author's selfrepresentation studied here. Its proportion is highest in the Anglophone corpus (see Table 5), with self-citations being the most frequent (70\%) - although this count includes also cases whose interpretation is ambiguous between reference to a person and reference to a work (see Section 3). Whereas self-citation in singleauthored papers may be used to ensure anonymity during the manuscript review process (admittedly, the anonymity of self-citation becomes pointless after the process is finalized, yet an author might simply fail to de-anonymise his/her selfcitations), self-citation in multiple-authored papers has an important identifying function which allows individual authors to stand out - compare Example (12) to an awkward (constructed) example one of us (Campbell-Kibler 2012) argued.

Campbell-Kibler (2012) argued that among Ohio speakers... (AN6)

\begin{tabular}{|l|rr|r|rr|rr|rr|r|}
\hline Corpus & \multicolumn{3}{|c|}{ Anglophone } & \multicolumn{3}{c|}{ Slovak } & \multicolumn{3}{c|}{ Non-native English } \\
\hline Perspective & Raw & $(\%)$ & NF & Raw & $\mathbf{( \% )}$ & NF & Raw & $(\%)$ & NF \\
\hline Initials & 0 & $(0 \%)$ & 0.0 & 24 & $(49 \%)$ & 1.5 & 0 & $(0 \%)$ & 0.0 \\
\hline Self-citations & 59 & $(70 \%)$ & 2.3 & 7 & $(14 \%)$ & 0.4 & 2 & $(20 \%)$ & 0.2 \\
\hline Self-mention terms & 25 & $(30 \%)$ & 1.0 & 18 & $(37 \%)$ & 1.1 & 8 & $(80 \%)$ & 0.6 \\
\hline Total & $\mathbf{8 4}$ & $(100 \%)$ & 3.3 & $\mathbf{4 9}$ & $(100 \%)$ & 3.1 & $\mathbf{1 0}$ & $(100 \%)$ & 0.8 \\
\hline
\end{tabular}

Table 5: The frequency of the third person perspective in the corpora, both raw and normalized (NF) to 10,000 words 
Similarly, self-mention terms are often employed to uniquely identify one of the authors, as in Example (13), or to acknowledge a contribution of people other than the authors, as in Example (14).

(13) The LE [language educator] (Wette) has had experience of designing and teaching a number of different EMP courses for undergraduate and qualified medical professionals. The ME [medical educator] (Hawken) is a qualified general practitioner and communication skills specialist, and at the time of the study had overall responsibility for CCS training for students in the undergraduate medical programme. (AN27)

(14) The NA [needs analysis] was conducted by a faculty member (Long), together with M.A. and Ph.D. students from two different institutions who were enrolled in a 2010 TBLT seminar. ... From the outset, the research team paid particular attention to creating and implementing a methodologically sound NA. (AN22)

In some cases, self-mention terms are used in acknowledgements, as in Example (15), which contrasts with the more personal type of acknowledgements we saw in Example (11).

The authors extend thanks to the editors... (AN10)

In the Slovak corpus, the most frequent type of the third person perspective are initials (49\%), which do not appear at all in the other two corpora. Author's initials as well as self-mention terms in the Slovak texts are used in notes supplying a translation of a foreign term or quote, e.g. in Example (16), an explanation of a cited quotation, e.g. the first use of the initials in Example (17), or a signal that a graphical highlight was added by the author, e.g. the second use of the initials in (17).

(16) “Значит, сработала эта хреновина..."

1 "Tak predsa fungoval ten nepodarok..." (Preklad autora.) (SK26)

Russian text with a footnote translating the Russian text, followed by (Translation by the author.)

(17) Na druhej strane však J. Mistrik uvádza, že "o účasti adresáta ako štýlotvorného činitel'a [podielajúceho sa na výslednej podobe komunikácie; pozn. J. K.] možno hovorit' iba pri dialógu" (Mistrík 1997, s. 413; kurzíva J. K.) (SK13)

[On the other hand, however, J. Mistrík states that "the participation of an addressee as a style-making element [participating at the final form of communication; note by J. K.] can only be talked about in the case of dialogue" (Mistrík 1997, s. 413; italics by J. K.).] 
The use of the third person makes Slovak authors appear as non-participants of the communicative exchange, resulting in unobtrusiveness of their presence in the given notes. In contrast, Anglophone writing makes use of the first person at such instances:

... Ebert and Zurstadt (1930:2) report movement toward English in the following (original orthography followed by our own translation): (AN28)

Whereas Gentile conveyed luxury by the textures of fabrics, the descriptive realism of surface, Angelico chose to emphasize less material qualities of refined outline, balanced interval, and unsullied color. (my emphases) (AN26)

In the non-native English corpus, there are few occurrences of the third person perspective, with as many as five of these (50\%) appearing in a single paper. I conclude, therefore, that Slovak authors rarely use the third person perspective when writing in English. There may be several possible reasons for the low occurrence of the third person perspective in non-native English writing. First, Slovak authors publishing in English-medium Slovak journals (unlike in large international journals) might feel little competitiveness and pressure to promote their previous published work by self-citations: Note that there are only two self-citations in two papers in the whole non-native English corpus. Second, the authors writing in English typically cite literature written in English and therefore they do not need to translate foreign terms or quotes, as is the case with Slovak texts (cf. Example (16) above). Alternatively, the authors retain Slovak quotes without a translation, as in Example (20).

S. Holeckková (online) provides the following explanation of the function of the above mentioned object:

Cechové zvolávacie tabul'ky slúžili na zvolávanie všetkých členov cechu na cechové schôdze. Dokazovali legitimitu, právo cechmajstra ako zákonne voleného predstaveného cechu. Tabul'ka zároven̆ znamenala, že osoba, ktorá sa ňou preukazuje je hodnoverná. Niekedy bola so schránkou na uloženie správy.

The use of a meanigful [sic] explanatory text would make the exhibits (cechové tabul'ky) more attractive and would withdraw them from the anonymous mass of the past objects lacking their history. (NNE25)

Third, the acknowledgements in the non-native English corpus are completely impersonal, referring to a grant scheme rather than expressing gratitude of the author to other persons, as was seen in the Anglophone corpus, see Example (15). The impersonality of acknowledgements in the non-native corpus may be due to the context of publication of the papers, but its discussion is beyond the scope of this paper. Lastly, as there are only three multiple-authored papers in the 
corpus (see Table 1), there are fewer needs overall to uniquely identify one of the authors, as is the case in the Anglophone corpus, see Example (12).

\section{Conclusions and implications}

This paper has explored author's self-representation in academic discourse. Options of author's personal presence range from the collective plural perspective, i.e. positioning oneself as part of a society or of an academic community, or engaging the reader in a dialogue, through the reader-exclusive perspective including both singular and plural perspectives, to the third person perspective realized as author's initials, self-citations, and self-mention terms. Authors' choice from among these options is a reflection of their languages and academic cultures.

From the point of view of language, authors exploit the ambiguity of the first person plural pronouns and unobtrusiveness of the author's initials and in Slovak also of marking the person by verb endings. The choice to represent oneself unobtrusively or more visibly, however, depends on cultural and contextual determinants. Namely, the study suggests that Anglophone academic culture is rather individualistic, as indicated by predominance of the reader-inclusive perspective in the collective plural perspective and of the reader-exclusive perspective overall, the use of the first person singular by single authors, and the use of the third person for unique identification of one of multiple authors. All of these features lay emphasis on both the writer and the reader as an individual. This tendency is further intensified by the competitiveness of large international journals from which most of the texts in the corpus were taken. In contrast, Slovak academic culture appears largely collectivist, a tendency strengthened by the more local context of publication of the respective texts both in Slovak and in non-native English. The collectivist nature of Slovak culture is illustrated by a high degree of the collective plural perspective overall (especially in the non-native English corpus), dominance of the reference to people in general in the collective plural perspective, and the use of the plural by single authors. This collectivism might be a remnant of the communist past of the nation; compare Khoutyz (2013: 8), who argues that the use of authorial we in Russian research articles is due to "the influence of the Soviet era [...], when the Soviet government deprived Russian-speaking academics of any incentive to express individuality and personal involvement". While some single authors choose to present themselves with the singular forms, a number of Slovak authors limit their use of the singular perspective to acknowledgements, especially in the Slovak language. When an individualisation in a note is needed in Slovak writing, the unobtrusive third person perspective is preferred. 
The research has implications for the study of intercultural rhetoric as well as for the teaching of English for Academic Purposes to speakers of other languages. Namely, research should reveal to what extent and how the collectivist nature is reflected in academic writing in languages of other post-communist cultures. Such research should in turn inform the teaching of academic English, which needs to make students aware of the use of individualistic and collectivist elements in academic writing in their own culture on the one hand, and in English on the other hand, so that they can make conscious choices of the options of author's presence tailored to their target audience.

\section{Notes}

1 The research reported in this paper was supported by grant Personálna a sociálna deixa $v$ slovenčine 'Personal and social deixis in Slovak', grant reference 1/0099/16, from the Scientific Grant Agency VEGA, Slovakia.

I would like to express my gratitude to two anonymous reviewers for their comments on a previous version of this paper, which have greatly improved the manuscript. All the remaining errors are mine.

2 Another influential taxonomy was proposed by Hyland (2002a). As his taxonomy involves only reader-exclusive uses, I do not deal with it in this paper.

3 Admittedly, this rules out many native speakers with a foreign name and/or affiliation, but it increases the chances of nativeness.

4 The same problem for non-native English writing by Czech linguists is reported by DontchevaNavratilova (2014).

5 The journal Jazyk a kultúra, thanks to its multi-lingual policy, was a source of both Slovak and non-native English texts.

6 While this option was not anticipated, it was found in the data during the course of the research.

\section{References}

Anthony, L. (2014) AntConc (Version 3.4.4) [Computer Software]. Tokyo, Japan: Waseda University. Available at: http://www.laurenceanthony.net/software/antconc/

Anthony, L. (2015) AntFileConverter (Version 1.2.0) [Computer Software]. Tokyo: Waseda University. Available at: http://www.laurenceanthony.net/software/antfileconverter/

Biber, D., Johansson, S., Leech, G., Conrad, S. and Finegan, E. (1999) Longman Grammar of Spoken and Written English. Harlow: Pearson.

Burgess, S. (2002) 'Packed houses and intimate gatherings: Audience and rhetorical structure.' In: Flowerdew, J. (ed.) Academic Discourse. London: Pearson.

Chamonikolasová, J. (2005) 'Comparing the structures of academic texts written in English and Czech.' In: Huttová, M., Böhmerová, A., Keníž, A. and Tandlichová, E. (eds) Slovak Studies in English I. Bratislava: Comenius University. 77-84.

Chang, Y. Y. and Swales, J. (1999) 'Informal elements in English academic writing: Threats or opportunities for advanced non-native speakers.' In: Candlin, C. N. and Hyland, K. (eds) Writing: Texts, Processes and Practices. London: Longman. 145-167.

Charles, M. (1999) 'Aspects of the author's voice in three academic research articles.' In: Thompson, P. (ed.) Issues in EAP Writing Research and Instruction. Reading: The University of Reading. 71-83. 
Čmejrková, S. (2007) 'The (re)presentation of the author in Czech and Slovak scientific texts.' Jezik in slovstvo 52(3-4), 21-31.

Čmejrková, S. and Daneš, F. (1997) 'Academic writing and cultural identity: The case of Czech academic writing.' In: Duszak, A. (ed.) Culture and Styles of Academic Discourse. Berlin: Mouton de Gruyter. 41-62.

Connor, U., Nagelhout, E. and Rozycki, W. V. (eds) (2008) Contrastive Rhetoric. Reaching to Intercultural Rhetoric. Amsterdam: John Benjamins.

Dontcheva-Navratilova, O. (2013) 'Authorial presence in academic discourse: Functions of author-reference pronouns.' Linguistica Pragensia 23(1), 9-30.

Dontcheva-Navratilova, O. (2014) 'Autorovy role a funkce zájmen v první osobě v odborných článcích anglofonních a českých lingvistů.' Časopis pro moderní filologii 96(1), 42-57.

Duszak, A. (1994) 'Academic discourse and intellectual styles.' Journal of Pragmatics 21(3), 291-313.

Duszak, A. (1997) 'Cross-cultural academic communication: A discourse-community view.' In: Duszak, A. (ed.) Culture and Styles of Academic Discourse. Berlin: Mouton de Gruyter. 11-40.

Flowerdew, J. (2001) 'Attitudes of journal editors to nonnative speaker contributions.' TESOL Quarterly 35(1), 121-150.

Galtung, J. (1981) 'Structure, culture, and intellectual style: An essay comparing saxonic, teutonic, gallic and nipponic approaches.' Information 20(6), 817-856.

Harwood, N. (2005) "We do not seem to have a theory... The theory I present here attempts to fill this gap": Inclusive and exclusive pronouns in academic writing.' Applied Linguistics 26(3): 343-375.

Hewings, M. and Hewings, A. (2002) "“It is interesting to note that...": A comparative study of anticipatory "it" in student and published writing.' English for Specific Purposes 21(4), 367-383.

Hyland, K. (2001) 'Humble servants of the discipline? Self-mention in research articles.' English for Specific Purposes 20(3), 207-226.

Hyland, K. (2002a) 'Authority and invisibility: Authorial identity in academic writing.' Journal of Pragmatics 34(8), 1091-1112.

Hyland, K. (2002b) 'Options of identity in academic writing.' ELT Journal 56(4), 351-358.

Hyland, K. (2011) 'Projecting an academic identity in some reflective genres.' Ibérica $21,9-30$.

Hyland, K. and Tse, P. (2012) "'She has received many honours": Identity construction in article bio statements.' Journal of English for Academic Purposes 11(2), 155-165.

Ivanič, R. and Camps, D. (2001) 'I am how I sound: Voice as self-representation in L2 writing.' Journal of Second Language Writing 10(1-2), 3-33.

Kaplan, R. B. (1966) 'Cultural thought patterns in inter-cultural education.' Language Learning 16(1-2), 1-20.

Khoutyz, I. (2013) 'Engagement features in Russian \& English: A cross-cultural analysis of academic written discourse.' Teachers College, Columbia University Working Papers in TESOL \& Applied Linguistics 13(1), 1-20.

Khoutyz, I. (2015) 'Engagement in written academic discourse: A cross-cultural study of Russian and English research articles.' International Journal of Russian Studies 4(2), 135-160.

Kuo, C. H. (1999) 'The use of personal pronouns: Role relationships in scientific journal articles.' English for Specific Purposes 18(2), 121-138. 
Lafuente Millán, E. (2010) “"Extending this claim, we propose...”: The writer's presence in research articles from different disciplines.' Ibérica 20, 35-56.

Martínez, I. A. (2001) 'Impersonality in the research article as revealed by analysis of the transitivity structure.' English for Specific Purposes 20(3), 227-247.

Martínez, I. A. (2005) 'Native and non-native writers' use of first person pronouns in the different sections of biology research articles in English.' Journal of Second Language Writing 14(3), 174-190.

Master, P. (1991) 'Active verbs with inanimate subjects in scientific prose.' English for Specific Purposes 10(1), 15-33.

McCrostie, J. (2008) 'Writer visibility in EFL learner academic writing: A corpus-based study.' ICAME Journal 32(1), 97-114.

Molino, A. (2010) 'Personal and impersonal authorial references: A contrastive study of English and Italian linguistics research articles.' Journal of English for Academic Purposes 9(2), 86-101.

Mur Dueñas, P. (2007) "I/we focus on...": A cross-cultural analysis of self-mentions in business management research articles.' Journal of English for Academic Purposes 6(2), 143-162.

Mur Dueñas, P. and Šinkūnienè, J. (2016) 'Self-reference in research articles across Europe and Asia: A review of studies.' Brno Studies in English 42(1), 71-92.

Ó Duibhín, C. (2016) Windows Interface for TreeTagger [Computer Software]. S. 1. Available at: http://www.smo.uhi.ac.uk/ oduibhin/oideasra/interfaces/winttinterface. htm

Pho, P. D. (2008) 'Research article abstracts in applied linguistics and educational technology: A study of linguistic realizations of rhetorical structure and authorial stance.' Discourse Studies 10(2), 231-250.

Schmid, H. (2009) TreeTagger. A part-of-speech tagger for many languages. [Computer Software]. Stuttgart: University of Stuttgart. Available at: http://www.cis.unimuenchen.de/ schmid /tools/TreeTagger/

Scollon, R. (1994) 'As a matter of fact: The changing ideology of authorship and responsibility in discourse.' World Englishes 13(1), 33-46.

Stašková, J. (2005) 'Options of identity: Authorial presence in research article abstracts.' In: Huttová, M., Böhmerová, A., Keníž, A. and Tandlichová, E. (eds) Slovak Studies in English I. Bratislava: Comenius University. 77-84.

Sudková, M. (2010) The Expression of Interpersonal Metadiscourse in English and Czech Academic Texts. MA Thesis. Charles University in Prague.

Swales, John M. (1990) Genre Analysis: English in Academic and Research Settings. New York: Cambridge University Press.

Tang, R. and John, S. (1999) "The "I" in identity: Exploring writer identity in student academic writing through the first person pronoun.' English for Specific Purposes 18, S23-S39.

Tarone, E., Dwyer, S., Gillette, S. and Icke, V. (1981) 'On the use of the passive in two astrophysics journal papers.' The ESP Journal 1(2), 123-140.

Vassileva, I. (1998) 'Who am I/who are we in academic writing?' International Journal of Applied Linguistics 8(2), 163-185.

Walková, M. (2008) 'Author's voice in journal articles.' In: Pavlovová, J. and Mihoková, K. (eds) Cudzie jazyky - celoživotná výzva: Zborník z medzinárodnej konferencie. Košice: Technical University of Košice. 166-169.

Walková, M. (2014) 'Rozdiely medzi slovenským a angloamerickým odborným štýlom na príklade jazykovedných textov.' Jazyk a kultúra 5(19-20), sine pagina. 
Webb, C. (1992) 'The use of the first person in academic writing: Objectivity, language and gatekeeping.' Journal of Advanced Nursing 17(6), 747-752.

Zapletalová, G. (2009) Academic Discourse and the Genre of Research Article. Banská Bystrica: Matej Bel University.

Milada Walková is an Assistant Professor at the Technical University of Košice, Slovakia, where she teaches English for Specific Purposes and English for Academic Purposes. In her research she focuses on academic writing from the contrastive linguistic and intercultural rhetoric perspective.

Address: Mgr. Milada Walková, PhD., Department of Languages, Technical University of Košice, Vysokoškolská 4, 04200 Košice, Slovakia. [e-mail: milada.walkova@tuke.sk] 